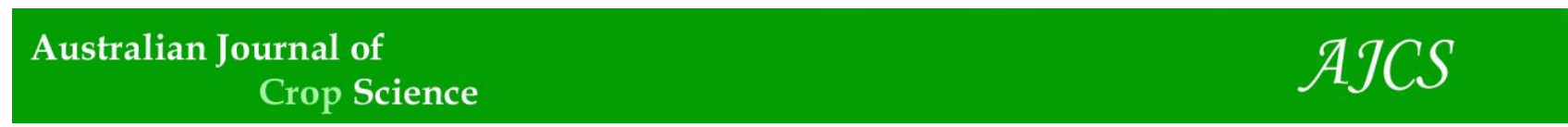

AJCS 10(6):819-823 (2016)

ISSN:1835-2707

DOI: $10.21475 / a j c s .2016 .10 .06 . p 7342$

\title{
Effect of processing stages in the physiological quality of maize seeds
}

\author{
Thiago Alberto Ortiz ${ }^{1 \dagger *}$, Marcio Antônio Nicoletti ${ }^{1,2 \dagger}$, Lúcia Sadayo Assari Takahashi $^{3}$ \\ ${ }^{1}$ Post Graduate Program in Agronomy, State University of Londrina (Universidade Estadual de Londrina-UEL), \\ 6001, 86051-990, Londrina, Brazil. CAPES (Coordenação de Aperfeiçoamento de Pessoal de Nível Superior \\ [Brazilian Federal Agency for Support and Evaluation of Graduate Education]). (55) 43 9867-2435 \\ ${ }^{2}$ Sementes BALU, Rua Águia, 167, 86707-190, Arapongas, Paraná, Brasil \\ ${ }^{3}$ Agronomy Department, UEL, 6001, 86051-990, Londrina, Brazil. (55) 43 9922-3587 \\ ${ }^{\dagger}$ Equal contribution, both authors are PhD students.
}

*Corresponding author: thiago.ortiz@hotmail.com

\begin{abstract}
Seeds are the primary input in the maize production process, and monitoring seeds through the processing stages is an essential practice in the production chain, particularly when identifying critical points in the process that can interfere with the final seed quality. Therefore, the objective of this study was to evaluate the effect of processing stages in the physiological quality of Balu 761 maize hybrid seeds. Seeds from the Balu 761 maize hybrid obtained during processing (receipt, shelling, drying, threshing, grading and bagging) were used. The experimental design was completely randomized with four replications. Physiological seed quality was evaluated using germination, accelerated aging, cold testing, electrical conductivity and seedling length tests, with the latter used to determine the length and dry weight of the shoot and root. The data were subjected to a variance analysis, and the means were compared using the Scott-Knott test $(p \leq 0.05)$. The physiological quality of Balu 761 maize hybrid seeds was enhanced during processing because the percentage of normal seedlings from cold test, as well as the root length, shoot length and shoot dry weight were optimized when considering the process as a whole, which contributed to the increased vigor of both seeds and seedlings. The germination and accelerated aging tests were not influenced by the processing stages.
\end{abstract}

Keywords: accelerated aging; cold test; electrical conductivity; germination; seedling length test; Zea mays.

Abbreviations: AA_accelerated aging; CT_cold test; EC_electrical conductivity; FGC_first germination count; G_germination; RDW_root dry weight; RL_root length; SDW_shoot dry weight; SL_shoot length.

\section{Introduction}

Maize is distinguished by its economic importance, with $51.3 \%$ of the world's production coming from the Americas. The top five producers of maize grain are the United States, China (mainland), Brazil (80.3 million tons ${ }^{-1}$ ), Argentina and Ukraine, and the top five maize seed producers are China, China (mainland), India, the United States and Brazil (Faostat, 2013). Brazil has approximately 15.4 million hectares of cultivated area dedicated to maize (crop year 14/15); the major producing states are Rio Grande do Sul, Minas Gerais and Paraná (4.7 thousand tons $\left.\mathrm{s}^{-1}\right)$, with Paraná leading in productivity (8.654 $\mathrm{kg} \mathrm{ha}^{-1}$ ) (Conab, 2015). Despite the importance of maize to the country, Brazil is not among the top five countries delivering the highest yields (Faostat, 2013); thus, there is a demonstrated need to optimize the maize supply chain. In maize seed production, consistent attention to the quality of the final product ensures that the adopted practices are favorable to market requirements. Quality and uniformity of seeds are essential in obtaining a suitable stand and high productivity (Trogello et al., 2013). The processes related to sowing, harvesting, processing, drying and storage, in addition to genetic and cultivation aspects, can affect seed quality (Menezes et al., 2002; Martins et al., 2005; Ferreira and Sá, 2010). Seedprocessing units (SPUs) classify seeds according to the size, shape and availability of a homogeneous product free of impurities, thereby facilitating the process of mechanized sowing and maintaining seed quality suited to the process (Trogello et al., 2013). Seed processing comprises a set of operations that begin with the receipt of the material at the processing unit and then proceed through later stages such as shelling, drying, threshing, grading and finishing with bagging and subsequent distribution. This last stage constitutes an essential step in producing high-quality seeds and must be performed appropriately; otherwise, the previous efforts in developing the material and using appropriate culture techniques are wasted (Fessel et al., 2003; Silva et al., 2011). Compared to other crops, maize processing is highly specialized from an operational standpoint; grading is required due to significant variations in the size, shape and quality of the seeds, depending on their position on the cob (Ferreira and Sá, 2010). Maize seed processing requires that all post-harvest seed operations are conducted in a specific sequence to improve quality by removing impurities and poor-quality seeds, in addition to appropriate grading. However, these processes can cause mechanical damage that consequently leads to a reduction in the physiological quality of the seed (Fornasieri Filho, 1992). Fessel et al. (2003) observed that mechanical damage can occur in maize seeds at each processing stage and that this damage is cumulative; however, this processing can enhance the quality of a lot in 
terms of germination, vigor and health when correctly performed, thus fulfilling its overall objective. Improvements in the quality of maize seeds were observed by Ferreira and Sá (2010) after processing; the seeds obtained after processing via a gravity separation table and those ready for bagging demonstrated the best physiological quality. In contrast, Paiva et al. (2000) observed that processing reduced vigor; however, the processing did not affect the germination of maize seeds that were mechanically harvested.

The seed is the primary input in the maize production process. The monitoring of seed lots during processing is an essential practice in the production chain of major crops, particularly when identifying critical points during the process that can interfere with the final seed quality. Therefore, the objective of this study was to evaluate the effect of processing stages in the physiological quality of Balu 761 maize hybrid seeds.

\section{Results and Discussion}

First germination count, germination, accelerated aging, cold test and electrical conductivity

Table 1 shows the results obtained from the first germination count, germination, accelerated aging, cold test and electrical conductivity evaluations of Balu 761 hybrid maize seeds at different processing stages (receipt, shelling, drying, threshing, grading and bagging).

\section{First germination count}

Based on the seed vigor from the first count of the germination test, the maize seed quality increased with advancing processing stages; beginning at threshing, seed vigor showed no significant difference compared to subsequent stages, differing from the initial stages (Table 1). Pereira et al. (2012) also obtained increased vigor in rice seeds as the processing progressed.

For Fessel et al. (2003), the first count of the maize seed germination showed significant differences among the processing stages; however, there was no statistically significant difference of this variable between seeds collected at receipt and post-bagging. Giomo et al. (2008) also observed significant differences of the first count during the processing of coffee seeds but did not find a clear trend.

However, Silva et al. (2011), in working with four soybean cultivars, observed decreased seed vigor after beginning processing in one of the cultivars but not in the others. Thus, is possible to observe that seeds of different species have a characteristic behavior during processing stages when considering the first germination count variable.

\section{Germination and accelerated aging}

In the germination and accelerated aging tests, there was no influence of the processing stages at which the materials were collected on the physiological quality of the maize seeds (Table 1). Paiva et al. (2000), also working with maize seeds, observed that processing did not affect seed germination, and Silva et al. (2011) did not observe an influence of the processing stages on the seed vigor of four soybean cultivars when using an accelerated aging test. The results of both of these groups corroborate the results obtained in this study.

However, other studies observed significant differences among the processing stages that showed improvement in the physiological quality of seeds with progressive processing stages; these include Fessel et al. (2003), Giomo et al. (2008) and Pereira et al. (2012) for maize, coffee and rice seeds, respectively.

The seeds showed a high percentage of germination at the assessed processing stages, exceeding $98 \%$ in all of the processing stages according to the germination test. The high physiological quality of the material was maintained from the beginning of the processing. Seeds with high physiological quality are desirable because that they produce larger seedlings that lead to higher rates of crop growth; in contrast, the use of seeds of low physiological quality can lead to reduced, delayed and uneven field emergence (Höfs et al., 2004).

Schuch et al. (2009) observed that soybean seeds with high physiological potential provided a $25 \%$ increase in grain yield compared with the final yield of plants grown from seeds with low physiological potential. Likewise, Kolchinski et al. (2005) observed that the use of high-vigor seeds provided increases of over $35 \%$ in seed yield compared to the use of low-vigor seeds. According to Tonin et al. (2000), cultivars producing seeds with the best physiological quality generally show greater tolerance to water-stress conditions in the field.

\section{Cold test}

Cold test (Table 1) demonstrated a significant difference in the physiological quality of maize seeds at different processing stages; the seeds collected at grading showed a smaller percentage of normal seedlings compared with seeds at other stages. However, the most important factor was the reestablishment of high quality at the end of the process. Working with maize seeds, Menezes et al. (2002) and Fessel et al. (2003) also observed significant differences in the percentage of normal seedlings subjected to cold test from different processing stages.

When performing cold test, Fessel et al. (2003) observed an increase in the physiological quality of the seeds at the final processing stages, with no significant differences between seeds collected at the initial and final stages. The same pattern was observed in this study: the seeds collected at the initial stages, such as at receipt, did not differ statistically from seeds collected at bagging.

\section{Electrical conductivity}

When assessing seed vigor using an electrical conductivity test, an effect of processing stages on the physiological quality of maize seeds was apparent due to the increased leaching of metabolites into the solution; this may have been caused by mechanical damage to the seeds, possibly causing a cumulative effect on their integument (Table 1). Other authors have noticed a significant difference between processing stages when assessing the electrical conductivity of maize seeds (Menezes et al., 2002; Fessel et al., 2003).

Again, the behavior observed by Fessel et al. (2003) corroborates that of this study, with a tendency toward increased leaching in the solution as the processing of maize seeds advanced. Silva et al. (2011), working with different soy materials, observed no effect of processing on seed vigor when using electrical conductivity test.

According to Carneiro et al. (2003), mechanical damage caused by the action of physical agents on maize seeds, including damage caused during processing, is viewed as a major cause of reduced quality. Moreover, in addition to having an immediate effect on quality, mechanical damage predisposes the seeds to faster deterioration due to the increase in respiration and electrolyte leakage, thus 
Table 1. Means of the first germination count (FGC - \%), germination (G - \%), accelerated aging (AA - \%), cold test (CT - \%) and electrical conductivity $\left(\mathrm{EC}-\mu \mathrm{S} \mathrm{cm}{ }^{-1}\right)$ analyses of Balu 761 hybrid maize seeds at different processing stages.

\begin{tabular}{lccccc}
\hline Processing stages & FGC & G & AA & CT & EC \\
\hline Receipt & $52.5 \mathrm{~b}$ & 100.0 & 91.5 & $96.5 \mathrm{a}$ & $0.0550 \mathrm{~d}$ \\
Shelling & $40.0 \mathrm{c}$ & 98.5 & 98.0 & $98.0 \mathrm{a}$ & $0.0725 \mathrm{c}$ \\
Drying & $61.0 \mathrm{~b}$ & 98.5 & 98.5 & $97.5 \mathrm{a}$ & $0.1025 \mathrm{~b}$ \\
Threshing & $86.0 \mathrm{a}$ & 100.0 & 99.0 & $98.0 \mathrm{a}$ & $0.0950 \mathrm{~b}$ \\
Grading & $94.0 \mathrm{a}$ & 99.0 & 94.0 & $94.0 \mathrm{~b}$ & $0.1000 \mathrm{~b}$ \\
Bagging & $95.0 \mathrm{a}$ & 98.5 & 97.0 & $98.0 \mathrm{a}$ & $0.1125 \mathrm{a}$ \\
\hline$p$-value & $0.0000^{*}$ & $0.0917^{\mathrm{ns}}$ & $0.4346^{\mathrm{ns}}$ & $0.0056^{*}$ & $0.0000^{*}$ \\
CV $(\%)$ & 8.36 & 0.97 & 6.05 & 1.43 & 6.73 \\
${ }^{\mathrm{n} s}$ Not significant, ${ }^{*}$ Significant $(p<0.05)$. & & & &
\end{tabular}

Table 2. Mean shoot length (SL - cm), root length (RL - cm), shoot dry weight (SDW - g) and root dry weight (RDW - g) of Balu 761 hybrid maize seeds at different processing stages.

\begin{tabular}{lcccc}
\hline Processing stages & SL & RL & SDW & RDW \\
\hline Receipt & $13.8 \mathrm{~b}$ & $22.7 \mathrm{~b}$ & $0.783 \mathrm{~b}$ & $0.552 \mathrm{~b}$ \\
Shelling & $13.8 \mathrm{~b}$ & $22.8 \mathrm{~b}$ & $0.800 \mathrm{~b}$ & $0.528 \mathrm{~b}$ \\
Drying & $14.7 \mathrm{a}$ & $22.9 \mathrm{~b}$ & $0.843 \mathrm{~b}$ & $0.593 \mathrm{a}$ \\
Threshing & $14.8 \mathrm{a}$ & $23.4 \mathrm{~b}$ & $0.824 \mathrm{~b}$ & $0.579 \mathrm{a}$ \\
Grading & $14.5 \mathrm{a}$ & $23.9 \mathrm{a}$ & $0.894 \mathrm{a}$ & $0.596 \mathrm{a}$ \\
Bagging & $15.1 \mathrm{a}$ & $24.5 \mathrm{a}$ & $0.886 \mathrm{a}$ & $0.547 \mathrm{~b}$ \\
\hline$p$-value & $0.0125^{*}$ & $0.0072^{*}$ & $0.0052^{*}$ & $0.0386^{*}$ \\
CV $(\%)$ & 3.65 & 2.74 & 4.66 & 5.47 \\
\hline
\end{tabular}

${ }^{\mathrm{n} s}$ Not significant, ${ }^{*}$ Significant $(\mathrm{p}<0.05)$.

increasing the percentage of weakened and abnormal seedlings. This leads to susceptibility to microorganisms, sensitivity to fungicides and reduced storage potential (Bruggink et al., 1991; Smith and Berjak, 1995).

However, it must be noted that although the electrical conductivity test detected reduced vigor in maize seeds during the processing stages, most of the other variables assessed showed the opposite trend, indicating that the processing was fulfilling its purpose; in the end, the processing obtained numerous seeds with optimal physiological quality. Fessel et al. (2003) obtained similar results and also concluded from the results obtained by other tests that the processing of maize seeds significantly improved the quality.

\section{Shoot and root length and dry weight}

Table 2 shows the shoot and root length and the shoot and root dry weight of normal seedlings originating from the seedling length test in each of the assessed seed-processing stages. Based on the data shown in Table 2, there was an increase in shoot and root length, along with shoot dry weight, as the seeds passed through the processing stages, with no significant difference in shoot length from the drying stage until the end of the processing of the maize seeds. The increase in root length and shoot dry weight occurred at grading, with no significant difference from the subsequent step. However, as for root dry weight, there were no significant differences among the seeds collected at receipt, shelling and bagging stages, which had seedlings with lower root dry weights compared to the other processing stages that did not differ from each other.

Thus, the different processing stages contributed to improved seedling quality; that is, initial seedling growth was enhanced by the seed processing. According to Causse et al. (1995), initial growth is an important characteristic for the productive capacity of maize plants and is related to some key enzymes in the fixation and distribution of photoassimilates in the plant, as greater growth can increase the utilization of solar radiation available at the beginning of the crop cycle, thus intensifying vegetative growth (Almeida et al., 2003).

\section{Final considerations}

Seed processing is an indispensable practice in the production chain of major crops such as maize. When this processing is performed properly, the benefits prevail because there is improvement and/or maintenance of the physiological quality of the seed; thus, the goal of seed processing is accomplished with the removal of impurities and poor-quality seeds in addition to the classification of seeds, leading to lot standardization.

Thus, as observed in the variables under study, the physiological quality of the seeds was optimized during processing because the seed processing contributed to increased seed and seedling vigor, as evidenced by the increased seed vigor assessed in cold test and the root and shoot length and shoot dry weight assessed in the seedling length test. In addition, there were no significant differences in the viability and vigor of maize seeds between those collected at receipt and bagging, as observed from the germination and accelerated aging tests; the high initial vigor of the material was maintained.

\section{Materials and Methods}

\section{Study area characterization and plant material}

The plants of Balu 761 maize hybrid (Sementes Balu ${ }^{\circledR}$ ) were grown in Pitangueiras-PR in the 2012/2012 crop. The seeds were harvested when they reached the point of physiological maturity and subsequently processed. During the processing, seed samples were collected from six processing stages: receipt, shelling, drying, threshing, grading and bagging. The samples were then referred to the Laboratory of Plant Science at the Londrina State University, Londrina - Paraná state (PR), Brazil, where the seed analyses were carried out.

\section{Treatments}

The treatments consisted of collecting the samples of the maize seeds from the six processing stages:

1. Receipt: In this stage, the maize cobs were placed in metal hoppers with a $2.25 \mathrm{~m}^{3}$ capacity, $1.00 \times 1.50 \times 1.00 \mathrm{~m}$ 
rectangular dimensions, and a 1.00-m-high lower cone with a 24 " outlet. The collection of the sample was characterized as "Receipt."

2. Shelling: After receipt, the maize cobs were sent to shelling, where they passed through shellers with a 4 ton $\mathrm{h}^{-1}$ capacity per row. Then, the shellers supplied the material to a 4.50-m-long continuous mechanical conveyor belt with $16^{\prime \prime}$ cleats. In turn, the maize cobs were fed onto a 24", 6.00-mlong double-layer sorting conveyor belt. After this process, the seeds were collected and the sample was designated "Shelling."

3. Drying: In this step, a 15.00-m-long continuous mechanical conveyor belt with 16 " cleats received the maize cobs from the selection belt and then fed the drying chamber. The material passed through the drying chambers of the maize cobs. The drying chambers are made of brick and have a $384 \mathrm{~m}^{3}$ capacity with discharge ports in the roof, shutters for air circulation, guillotine doors and wavy back walls with holes. Furthermore, the chambers are composed of four W02 indirect-fired furnaces, manufactured with black ABNT 1020 plates that are $1 / 8$ " thick for the body and $1 / 4$ " thick for the deflectors. They are coated in refractory bricks in the firing chamber, with 76 DIN2440 pipes that are 4" in nominal diameter with a $4.25 \mathrm{~mm}$ wall thickness and a 5.00 -m-high chimney, in addition to a centrifugal fan (CW-1085 model) and axial fan (AW-1200 model). In the drying chambers, where the heat was produced by two furnaces fueled with wood and threshed maize cobs, the maize cobs were maintained at $40^{\circ} \mathrm{C}$. The temperature was continuously monitored using a temperature recorder and regulated as necessary. Drying was achieved by the wind produced by the motors and the heat produced by the furnace. After this process, the samples were collected and designated "Drying." 4. Threshing: After drying, the maize cobs were sent to threshers (CWA brand) with cylindrical rotors and interspersed rasp bars operated by a 20-hp engine at 300 RPM. After threshing, the sample was collected and designated "Threshing."

5. Grading: In this step, a lift was used to transport the seeds to the pre-cleaning machine. The pre-cleaning machine separated the seeds into three types: "good quality", "discard" and "return." Seeds considered "good quality" (the goal of the process) remained in the process and were transported by the lift to a gravity table. In this machine, seeds underwent the separation process and were classified as "good quality" and "discard." The "good quality" seeds were selected and transported by belt to a storage hopper known as the "lung" that fed the precision sizer. The seeds were then transported via a conveyor belt to the seed precision sizer for maize hybrids (Model 412, Carter Day). The precision sizer consists of four levels and has a total height of $20.70 \mathrm{~m}$. During this step, the seeds passed through sorting machines that used sieves to classify the seeds according to their size $(24,22,20,18$ and 16$)$ and their shape $(\mathrm{R}=$ round, $\mathrm{F}=$ flat, $\mathrm{S}$ = short, $\mathrm{M}=$ medium and $\mathrm{MT}=$ medium thickness). The seeds were classified according to the size and shape of the seed corresponding to the type of planting sieve. After classification in the sizer, a sample of seeds from the $20 \mathrm{M}$ screen were collected and designated "Grading."

6. Bagging: The seeds were then sent by a lift to a storage hopper that fed the seed treater. The seeds were treated with insecticide and fungicide (Pirimiphos-methyl (50\%), Deltamethrin $(2.5 \%)$ and Fludioxonil/metalaxyl) at the recommended doses and placed in the storage hopper of the scale, which was automatically activated to fill the packaging until a predetermined amount of seeds $(60,000$ seeds) was reached. After the packages were filled, they were sewn, sealed and affixed with an identification label. The packaged and labeled seeds were then stacked with the aid of a forklift. After this procedure, a sample was collected and designated "Bagging."

The humidity of the seeds was monitored during all stages. The seeds collected at receipt and shelling had approximately $26.5 \%$ moisture, whereas the moisture was $12 \%$ at the other stages. Two replicates of $60 \mathrm{~g}$ of maize were used to determine moisture in each collection, and the reading was performed using a bench grain moisture meter $\left(\right.$ GEHAKA ${ }^{\circledR}$, Model G810).

\section{Variables measured}

The experimental design was completely randomized with four replications. The seed quality was evaluated using the following tests:

Germination: 50 seeds were used per replicate and distributed between three sheets of "germitest" paper that were moistened with distilled water to two and a half times its dry weight. Rollers were then prepared and maintained in germinators at $25^{\circ} \mathrm{C}$. The evaluations were performed at days 4 (first count) and 7 after the beginning of the test (Brasil, 2009); the results are expressed as \% germination.

Accelerated aging: 50 seeds were used per replicate. The seeds were arranged on metal plates fixed inside crystal polystyrene boxes $\left(G^{2}\right.$ rbox ${ }^{\circledR}$ ) forming a single layer, and 40 $\mathrm{mL}$ of distilled water was added at the bottom. The boxes were placed in germinators at $42^{\circ} \mathrm{C}$ for $72 \mathrm{~h}$. The seeds were subsequently placed between three sheets of "germitest" paper that were moistened to two and a half times its dry weight with distilled water. Rollers were then prepared and maintained in germinators at $25^{\circ} \mathrm{C}$. The evaluation was performed four days after test implementation, and the results are expressed as the \% of normal seedlings.

Cold test: 50 seeds were used per replicate. The seeds were distributed between three sheets of "germitest" paper moistened to two and a half times its dry weight with distilled water. Rollers were then prepared that were wrapped in clear plastic bags and sealed with masking tape to prevent water loss by evaporation; these rollers were placed in germinators at $10^{\circ} \mathrm{C}$ for seven days. The parcels were subsequently transferred to a germinator at $25^{\circ} \mathrm{C}$; evaluations were performed after four days, with the results expressed as the \% of normal seedlings.

Electrical conductivity: 50 seeds were used per replicate and were placed in plastic cups containing $75 \mathrm{~mL}$ of distilled water. The parcels were incubated in a germinator at $25^{\circ} \mathrm{C}$ for $24 \mathrm{~h}$, after which the electrical conductivity was read using a $\mathrm{CD}-21^{\circledR}$ Digimed conductivimeter; the results are expressed in $\mu \mathrm{S} \mathrm{cm}^{-1}$.

Seedling length test: 20 seeds were used per replicate. The seeds were distributed between three sheets of "germitest" paper moistened to two and a half times its dry weight with distilled water. Rollers were then prepared and maintained in germinators at $25^{\circ} \mathrm{C}$. After seven days, the shoot and root lengths of all normal seedlings were recorded with the aid of a graduated ruler, with the mean values expressed in $\mathrm{cm}$. The shoots were then separated from the roots of all the seedlings, placed separately in paper bags identified and dried at $65^{\circ} \mathrm{C}$ for $24 \mathrm{~h}$. After this period, the material was weighed in an AW $320^{\circledR}$ Shimadzu digital analytical balance to determine the shoot and root dry weight; the results are expressed in $\mathrm{g}$.

\section{Statistical analysis}

The data were subjected to a variance analysis, and the means were compared using the Scott-Knott test $(p \leq 0.05)$. 


\section{Conclusions}

The physiological quality of Balu 761 maize hybrid seeds was enhanced during processing because the percentage of normal seedlings from cold test, as well as the root length, shoot length and shoot dry weight were optimized when considering the process as a whole, which contributed to the increased vigor of both seeds and seedlings. The germination and accelerated aging tests were not influenced by the processing stages.

\section{Acknowledgements}

The authors acknowledge the financial support of the CAPES (Coordenação de Aperfeiçoamento de Pessoal de Nível Superior [Brazilian Federal Agency for the Support and Evaluation of Graduate Education]) for granting scholarships to the first two authors and the Fundação Araucária (Araucária Foundation) for the productivity grant provided to the third author. In addition, the authors thank the Balu Group for their support.

\section{References}

Almeida ML, Sangoi L, Nava IC, Gálio J, Trentin PS, Rampazzo C (2003). Crescimento inicial de milho e sua relação com o rendimento de grãos. Cienc Rural. 33:189194.

Brasil - Ministério da Agricultura, Pecuária e Abastecimento (2009). Regras para análise de sementes. 1st edn. Mapa/ACS, Brasília.

Bruggink H, Kraak HL, Dijkema MHGE, Bekendam J (1991). Some factors influencing electrolyte from maize (Zea mays L.) kernels. Seed Sci Res. 1:15-20.

Carneiro V, Araújo EF, Miranda GV, Galvão JCC, Reis MS, David AMSS (2003). Efeito da debulha e da classificação sobre o tamanho e a qualidade de sementes de milhopipoca. RBMS. 2:97-105.

Causse M, Rocher JP, Pelleschi S, Barrière Y, Vienne D, Prioul JL (1995). Sucrose phosphate synthase: an enzyme with heterotic activity correlated with maize growth. Crop Sci. 35:995-1011.

Conab (2015). Acompanhamento de safra brasileira. grãos, vol 2 - Safra 2014/15, n. 9 - Nono levantamento. Conab, Brasília.

Faostat (2015). Food and agriculture organization of the united nations statistics division: Browse data Production/Crops. Accessed on 16/jul/2015, Available at: http://faostat3.fao.org/browse/Q/QC/E.

Ferreira RL, Sá ME (2010). Contribuição de etapas do beneficiamento na qualidade fisiológica de sementes de dois híbridos de milho. Rev Bras Sementes. 32:99-110.

Fessel AS, Sader R, Paula RC, Galli JA (2003). Avaliação da qualidade física, fisiológica e sanitária de sementes de milho durante o beneficiamento. Rev Bras Sementes. 25:70-76.

Fornasieri Filho D (1992). A Cultura do Milho. FUNEP, Jaboticabal.

Giomo GS, Nakagawa J, Gallo PB (2008). Beneficiamento de sementes de café e efeitos na qualidade fisiológica. Bragantia. 67:1011-1020.

Höfs A, Schuch LOB, Peske ST, Barros ACSA (2004). Emergência e crescimento de plântulas de arroz em resposta à qualidade fisiológica de sementes. Rev Bras Sementes. 26:92-97.
Kolchinski EM, Schuch LOB, Peske ST (2005). Vigor de sementes e competição intra-específica em soja. Cienc Rural. 35:1248-1256.

Martins GN, Silva RF, Araújo EF, Pereira MG, Vieira HD, Viana AP (2005). Influência do tipo de fruto, peso específico das sementes e período de armazenamento na qualidade fisiológica de sementes de mamão do grupo formosa. Rev Bras Sementes. 27:12-17.

Menezes NL, Lersch-Junior I, Storck L (2002). Qualidade física e fisiológica de sementes de milho após o beneficiamento. Rev Bras Sementes. 24:97-102.

Paiva LE, Medeiros Filho S, Fraga AC (2000). Beneficiamento de sementes de milho colhidas mecanicamente em espigas: efeitos sobre danos mecânicos e qualidade fisiológica. Ciênc Agrotec. 24:846-856.

Pereira CE, Albuquerque KS, Oliveira JA (2012). Qualidade física e fisiológica de sementes de arroz ao longo da linha de beneficiamento. Semin: Cienc Agrar. 33:2995-3002.

Schuch LOB, Kolchinski EM, Finatto JA (2009). Qualidade fisiológica da semente e desempenho de plantas isoladas em soja. Rev Bras Sementes. 31:144-149.

Silva RP, Teixeira IR, Devilla IA, Rezende RC, Silva GC (2011). Qualidade fisiológica de sementes de soja (Glycine max. L.) durante o beneficiamento. Semin: Cienc Agrar. 32:1219-1230.

Smith MT, Berjak P (1995). Deteriorative changes associated with the loss of viability of stored desiccations of seed associated mycoflora during storage. In: Jaime K, Galili G (ed) Seed development and germination. Marcel Dekker Inc., New York.

Tonin GA, Carvalho NM, Kronka SN, Ferraudo AS (2000). Influência do cultivar e do vigor no desempenho germinativo de sementes de milho em condições de estresse hídrico. Rev Bras Sementes. 22:276-279.

Trogello E, Nobre DAC, Kolling EM, Modolo AJ, Trogello AG (2013). Acompanhamento de uma unidade beneficiadora de sementes de milho - estudo de caso. RBMS. 12:193-201. 